\title{
Diego Sánchez Sarabia y las Antigüedades Árabes de España: los orígenes del proyecto *
}

\author{
Delfin Rodriguez Ruiz
}

El interés por la Alhambra de Granada ha conocido, desde la presencia de los Reyes Católicos en la ciudad, una fortuna desigual. Esa historia ha sido contada en innumerables ocasiones y desde distintas perspectivas. Las reformas iniciadas a finales del siglo $x \vee$ y comienzos del siguiente, las nuevas construcciones, las opiniones de los viajeros, españoles y extranjeros, las valoraciones de la arquitectura islámica, los coleccionistas y, también, el abandono, el saqueo y las destrucciones, han acompañado la compleja historia de la fortaleza y de los palacios nazaries hasta nuestros dias '.

Por otro lado, las demandas de ayuda para la conservación de sus edificios no cesaron desde el siglo XVI, realizadas por gobernadores, al-

- El presente trabajo constituye el capitulo segundo de un libro, de próxima publicación por el Colegio Oficial de Arquitectos de Madrid, con el titulo: La memoria frágil. José de Hermosilla y las Antigüedades Arabes de Espana.

La bibliografia sobre la fortaleza y los palacios de la Alhambra es enorme. Ademas de las muchas referencias que a lo largo de este estudio se harán a artículos y libros concretos, es necesario mencionar algunas obras que tienen por objeto privilegiado no sólo de los edificios, sino también de su misma historia e historiografia. Asi, con independencia de las guias de la ciudad, conviene consultar A Gallegn Burin. La Alhambra, Granada. 1963, con una cuidada y exhaustiva bibliografía; C. VINES MILLET, La Alhambra de Granada. Tres siglos de historia, Córdoba, 1982; id. Granada en los libros de viajes. Granada. 1982 y. en relacion al palacio de Carlos V, E. E. Rose nithal, El palacio de Carlos V en Gran.t. Madrid, 1988. Las referencias a los importantes estudios de R. CONTRERAS, F. RIAN, M Gomez moreno, L. Torres balbas, J. Bermudez Pareja, E. Garcia gomez, B. Pavon, etc.. podrán consultarse en las notas al texto. 
caides, arquitectos y maestros de obras, entre otros muchos. Con la creación de la Academia de San Fernando la atención a la fragilidad y deterioro de los palacios nazaries va a adquirir una nueva orientación. De esta forma, mientras se esperan iniciativas que permitan la reparación y conservación de la fortaleza y sus edificios, la nueva institución pretende salvar la memoria del conjunto, al menos desde el punto de vista figurativo. Así, en 1756, se van a tomar las primeras decisiones que habrán de culminar con el viaje, diez años después, de José de Hermosilla, Juan de Villanueva y Juan Pedro Arnal a Granada para dibujar sus antigüedades y realizar con ellas una publicación, origen de un más ambicioso proyecto, nunca realizado, para formar una colección de monumentos arquitectónicos españoles ${ }^{2}$.

En la Junta Ordinaria, celebrada el 14 de octubre de 1756, la Academia acuerda, deseando "conservar y propagar la noticia de nuestras Antiguedades y Monumentos singularmente de aquellas que están más expuestas a perecer con el transcurso del tiempo: $Y$ haviendo yo ${ }^{3}$ hecho presente que son de esta naturaleza varios Retratos de los Reyes Moros de Granada, que estan pintados al fresco en algunos techos del Castillo de la Alhambra, con los trages propios de sus tiempos...", encargar al presidente de la Chancilleria de Granada, Manuel de Villena, que se dirija al pintor Manuel Sánchez Ximénez, "Discipulo de la Academia de conocida avilidad", para que dibuje en papel los mencionados retratos, reservándose la Academia "otras providencias sobre iguales asuntos para en adelante ${ }^{4}$.

La divulgación de "nuestras Antiguedades» se plantea, pues, en un principio, como una tarea de urgencia, basada exclusivamente en la acepción figurativa de la memoria del pasado y en una idea de la conservación reducida a lo visual. El contenido del acuerdo de la Junta Ordinaria no contempla la posibilidad de una cintervención» para evitar el deterioro de las pinturas, sino, simplemente, una serie de recomendaciones encaminadas a lograr una pulcra exactitud en la representación de las imágenes, "con expresión de sus tamaños, colores de sus ropages y

En relación a la iniciativa de la Real Academia de San Fernando para realizar la edición de las Antiguedades Arabes de España. puede verse, además de las obras citadas en el capitulo anterior. C. BEDAT. L'Academie des Beaux-Arts de Madrid, 1744-1808. Toulouse. 1974.

${ }^{3}$ Se trata de Ignacio de Hermosilla. Secretario de la Academia y, por tanto. encargado de redactar las Actas de las Juntas.

- Actas de las Juntas Particulares y Ordinarias... desde el año de 1753 hasta el de 1757. A.S.F., sign.: $81 / 3$ 
todas las demás partes y menudencias que puedan conducir a su entero conocimiento". Lo que posteriormente habría de convertirse en un riguroso estudio y análisis de las antigüedades árabes, sobre todo por medio de una compleja utilización de los sistemas de representación de la arquitectura y de su capacidad para desvelar la lección compositiva y formal que encierra, nacia con una vocación anticuaria en la mejor tradición de los siglos anteriores, abriendo asi paso a una nueva consideración del coleccionismo de carácter institucional que la Academia confundio siempre con su declarada función tutelar del pasado.

Manuel Ximénez, como se le denomina con posterioridad en la documentación conservada, aceptó el encargo. Sin embargo, parece que no llevó a cabo la realización de los dibujos: "pasose mucho tiempo sin que este Artifice diese principio à la obra: de suerte que el Señor Viceprotector en mil setecientos sesenta escribió a don Luis Bucareli Alcayde de la Alhambra, sobre el asunto, para que buscase persona hábil en aquella Ciudad... en cinco de septiembre del dicho año avisó se habia valido de don Diego Sánchez Sarabia, Profesor de Pintura y Arquitectura, muy instruido en la antigüedad" 5 .

Bucareli expresaba a la Academia en 1760 que, debido a que es "obra de mucho trabajo", se "anime" a Sarabia dándole el título de Académico ${ }^{6}$. En diciembre de ese año envia las tres primeras pinturas al óleo, de las seis que habria de realizar, representando las que decoran las tres cubiertas de la Sala de los Reyes Moros en el patio de los Leones de la Alhambra. Con ellas mandaba también tres inscripciones árabes del mismo lugar. Acompañando esas obras, Sarabia remite una breve explicación «de la forma y materia de los adornos y Estucos que

Esto es lo que escribe Ignacio de HERMOSILLA, transcripción de un estado de la cuestión por él presentado a la Junta Particular el 18 de agosto de 1766. A.S.F., sign.: 121/3. Diego SANCHEZ SARABIA, pirtor y arquitecto, aun carece de un estudio adecuado. Las noticias sobre su actividad como pintor se hallan desperdigadas en diferentes publicaciones. básicamente guias de la ciudad de Granada. Entre otras obras suyas, cabe destacar el ciclo de pinturas realizado para el hospital e iglesia de San Juan de Dios de Granada: vease E. ISLa Mingorance, San Juan de Dios en Granada, Leon, 1979. Sarabia fue director de la Escuela de Bellas Artes de Granada, fundada en 1776. Otras obras suyas se hallan repartidas en diferentes edificios y museos granadinos como el de la Alhambra o en la iglesia de San José. El programa iconográfico del claustro de San Juan de Dios ha sido estudiado por J. M. LARIOS. El Claustro del Hospital de San Juan de Dios en Granada. Granada. 1979.

- Actas de la Junta Particular, correspondientes al 15 de septiembre de 1760. A.S.F. sign.: 121/3. En primer lugar se le concedio el titulo de Académico supernumerario en roviembre de 1760 por un cuadro que envió a los premios de pintura de ese año. El de Académico de mérito no lo obtendria hasta la finalización de todo su trabajo en la Alhambra. 
estan por bajo de las Bóbedas, y de su particular método de repartir las habitaciones" ' ${ }^{7}$. Aunque este primer informe no he podido localizarlo, las Actas de la Academia ofrecen un resumen en el que se describe su contenido. Además de lo señalado, "expresa que son muy recomendables por delicados y raros, y que se van arruinando cada dia: Que todos los patios, Anditos, Antecámara, Salones, Cenefas de Azulejos, tazas de las Fuentes, Bufetes de Mármol, y hasta las maderas de los vuelos de los tejados, están llenos de inscripciones muy singulares" ${ }^{8}$.

Con motivo del informe de Sarabia, la Academia decide darle unas "instrucciones» que amplian considerablemente el limitado encargo de las pinturas. En primer lugar, se le pide que copie las inscripciones y envie la versión castellana que poseia Luis Francisco Viana, de la Abadia del Sacromonte de Granada, ya que podian "contribuir mucho para ilustrar la Historia de la Nación». Luego se le detallan los criterios que debe seguir para la "delineación de los Palacios de la Alhambra de Granada y Copias de las Pinturas de sus Bóbedas" " .

No cabe duda que las primeras pinturas y el informe que envió Sarabia debieron causar una muy favorable impresión entre los académicos de San Fernando. Sólo asi se explica el importante cambio introducido en el proyecto original. Sin embargo, en la idea de la Academia, la colección de dibujos de los palacios de la Alhambra no estaba destinada a ser grabada, ni tan siquiera a enriquecer con nuevos modelos el incipiente "museo de arquitectura". Tan sólo se trataba de conservar la memoria figurativa de nuestras antigüedades sin intención de convertirla en instrumento pedagógico para la enseñanza de las Bellas Artes.

A pesar de todo, la Academia veia en esta ocasión la oportunidad de iniciar una colección de monumentos españoles, cuya función y modo de divulgación aún estaban por decidir. Es más, el destino inmediato del trabajo de Sarabia, según la instrucción, seria el de "enquadernarse para su más comodo uso y conservación", para ello se le prevenía que los

Las noticias están sacadas de las Actas de la Junta Particular correspondientes al 13 de diciembre de 1760. A.S.F.. sign.: 121/3.

* Ibíd. En el mismo informe. SaRABIa indica que la traducción de esas inscripciones hecha en el siglo XVI. "en tiempo del Señor Arzobispo Fray Fernando de Talavera". Ia conserva Luis Francisco Viana. canónigo del Sacromonte y empeñado. por esas fechas, en escribir una historia de la abadia y de los libros plúmbeos y reliquias que. descubiertos durante el reinado de Felipe II. dieron ocasion a una interesantisima polemica cultural y religiosa a la que habré de referirme a continuación.

La instrucción fue acordada en la Junta Particular del 13 de diciembre de 1760. Vease el apendice 5 . 
dibujos y "explicaciones" fueran hechos en "papeles iguales". Es decir, ni la exhibición en las salas de la Academia ni la estampación, ya fuera en láminas sueltas o en forma de libro, parecian, en principio, contemplarse.

Ya que en los tres primeros lienzos remitidos no figuraba indicación de escala alguna, la Academia recomienda a Sarabia en las instrucciones que "ponga un pitipié", ya fuera en la propia pintura o en su explicación, "para venir en conocimiento del tamaño de las figuras, y demas cosas que hay pintadas". Observación que, por otra parte, implica una rigurosa precisión sobre el carácter otorgado a las "copias" de las pinturas de la Sala de los Reyes, entendidas no tanto como "réplicas" -testimonio, a la vez, del interés de los pintores con respecto al pasado en cada momento histórico-, sino como "reproducciones" dotadas de un prioritario valor de información arqueólogica. La ocasión de poder comprobar que éste era el sentido con el que la Academia habia realizado el encargo se producirá años más tarde cuando, en 1766, se inicie el grabado de las seis pinturas de Sarabia. Las imprecisiones de los fondos y su inexactitud con respecto a los originales obligarán a solicitar de Hermosilla, ya en Granada por esas fechas, descripciones exactas con el fin de que los grabadores pudiesen incorporarlas a sus láminas ${ }^{10}$.

El significado del trabajo de Sarabia, ampliado, en 1760, también a la arquitectura de la Alhambra, adquiere su verdadera dimensión si se tiene en cuenta que su resultado es estricta consecuencia de las diferentes indicaciones contenidas en la "instrucción" que la Academia le proporciona como guia conceptual de su actividad, sobre todo si se la compara con la que seis años después recibirá Hermosilla para realizar su «viaje arquitectónico» a Granada. Así, mientras esta última plantea su redacción como una verdadera "arquitectura escrita", disponiendo un itinerario riguroso desde el plano general de la fortaleza a los detalles ornamentales del lenguaje arquitectónico, la instrucción de Sarabia es entendida como una suma de informaciones figurativas destinadas a configurar un "álbum de anticuario", con un sentido semejante al que presidiera la monumental obra de Bernard de Montfaucon, L'Antiquité expliquée et representée en figures, publicada en Paris entre 1719 y 1724.

Las primeras indicaciones pretenden, como ya hemos visto, que la precision documental de las pinturas de la Sala de los Reyes fuera lo más rigurosa posible: no basta su sola reproducción sino que se hacia

\footnotetext{
Sobre este asunto vease el capítulo cuarto.
} 
imprescindible dotarla de un valor arqueológico señalando su escala o "pitipié", ya fuera en propio lienzo o en "papel aparte". Las caracteristicas técnicas ("colores", "método", situación, etc.) y la época histórica de su realización constituyen el contenido de los siguientes puntos de la instrucción de 1760. El carácter documental atribuido por la Academia al trabajo de Sarabia puede confirmarse también por el interés puesto en que copie con rigor todo tipo de inscripciones, árabes o no, continuando asi una tradición secular que veía en ellas no sólo el testimonio más exacto del pasado, sino también la memoria más cualificada de las glorias de un país o de una ciudad. Lo que, además, explica el hecho de que Sarabia encontrase coherente introducir en su informe explicativo de la Alhambra toda una serie de antigüedades e inscripciones epigráficas descubiertas en la Alcazaba vieja de Granada, de cuyo polémico contenido él mismo era consciente.

El dibujo de las construcciones arquitectónicas no es contemplado de forma unitaria, como, sin embargo, ocurrirá con Hermosilla. lo que, por otra parte, habrá de tener importantes consecuencias en el mismo análisis arquitectónico de los palacios de la Alhambra y de Carlos V. Por el contrario, a Sarabia se le indica que dibuje, en primer lugar y aisladamente, "el paiacio hecho en tiempos de los árabes", con planos y alzados, y señalando las partes reformadas "por los cristianos" con un color diferente, asi como los elementos ornamentales. Este primer grupo de dibujos debería ir acompañado de una explicación de las características y tecnicas constructivas del edificio, con el fin de "formar un juicio caval del método de edificar observado por los árabes".

En segundo lugar, debía dibujar el Palacio de Carlos $V$ en proyección geómetrica, del mismo modo que el anterior, representando la planta, sección y fachada principal de la construcción. Dibujos que también debian ir acompañados de su pertinente explicación escrita.

Por último, la colección de dibujos debía incluir las inscripciones árabes de la Alhambra, así como su localización y transcripción. Todo ello, además, realizado en papeles de idéntico tamaño que posibilitaran su encuadernación.

Con estas instrucciones, Sarabia completó su trabajo. En diciembre de 1760, cuando se reciben las tres primeras pinturas, la Junta Particular acuerda ponerlas en bastidores nuevos y con "marcos decentes" para que puedan ser examinadas por "personas eruditas y curiosas, permitiendo copiarlas, pero sin dejarlas sacar de la Academia" ".

"Acta de la Junta Particular, del 13 de diciembre de 1760. ASF, sign.: 121/3. 
En junio de 1761 había remitido los otros tres lienzos que completaban la reproducción de las pinturas de las tres bóvedas de la Sala de los Reyes y también habia concluido el "Quaderno de las Ynscripciones". Se disponia, en esa fecha, a iniciar los planos de los palacios, preguntando a la Academia si debía realizarlos separadamente o unidos. A 10 que se le respondió, cambiando así la instrucción de 1760, que «después de un plano General en que se comprehendan aunque en pequeño, assi el Palacio de los Arabes como el del Señor Carlos Quinto, unidos como están, ha de hacer separados en mayor los planos y alzados particulares de uno y otro Palacio..." ${ }^{12}$.

A finales del mismo año estaba "poniendo en limpio" los dibujos del palacio árabe y había resuelto, siguiendo las instrucciones de la Academia, dividir en dos partes la obra relativa a los planos y alzados de arquitectura: "La primera, abraza el todo del Palacio Arave, sus plantas alta y baja, y algunos cortes de sus elevaciones interiores, con la situación del compartimiento de sus adornos, para venir en conocimiento a donde corresponden los diseños de ellos, los que van executados, unos del mismo tamaño que tienen, y los que van en menor lleban pitipie. Un Dibujo Scenografico de la Alhambra por la parte principal que cae a lo interior de la Ciudad, para que se vea con exactitud el efecto de la vista exterior de estas fábricas, y se pueda hacer un pleno conocimiento del todo (particularmente de la Arave) y en cuaderno separado la explicación circunstanciada de todo para venir en conocimiento con facilidad, segun lo pueda anotar con el mejor metodo, mi tal qual comprehension " ${ }^{13}$. El programa descrito por el propio Sarabia tiene un enorme interés para entender su intención con respecto al encargo de la Academia ya que entre sus dibujos conservados no se encuentran, desgraciadamente, los que representan la arquitectura, con excepción de un capitel. En todo caso, en el contexto general de su obra, compuesta de seis lienzos y sesenta y cuatro dibujos, solamente once contenian imágenes arquitectónicas, el resto eran inscripciones y motivos ornamentales del palacio nazari. De hecho las láminas de arquitectura de Sarabia sirvieron como instrumento de trabajo, para corregir sobre ellas escalas y cotas, a José de Hermosilla en 1766. Es posible que esa sea la razón que explique la

12 Actas de la Junta Particular, del veintisiete de junio de 1761. A.S.F., sign.: 121/3. En agosto del mismo año, las inscripciones fueron enviadas a la Academia de la Historia con el fin de que fueran estudiadas e interpretadas por Miguel Casiri.

${ }^{13}$ Actas de la Junta Particular, del diecisiete de diciembre de 1761. A.S.F., sign.: 121/3. 
ausencia de esos dibujos entre los conservados en la Academia de San Fernando.

"La parte segunda -continúa Sarabia- expresará con el mismo cuidado y método el Palacio del Señor Emperador así en sus plantas, corte interior, y dos fachadas principales, que son (a mi ver) de singular magestad y ciencia». Cabe señalar, en este momento, que todos esos dibujos serian, precisamente, los sustituidos por los realizados por Hermosilla, Villanueva y Arnal. Mientras que los que contenian inscripciones y motivos decorativos fueron los utilizados en la edición de las Antigüedades Árabes de España.

En agosto de 1762 envió Sarabia dos tomos, uno con "una vista de toda la Alhambra, dos Plantas, y muchas elevaciones del Palacio Arave, con un gran numero de dibujos de capiteles. Ynscripciones, Pavimentos, frisos, Arcos y otros Adornos: y otro tomo pequeño con una relación mui circunstanciada de todos ellos". La Academia elogió la inteligencia y exactitud del trabajo de Sarabia y, como consecuencia, fue nombrado Académico de Mérito, pero lo más importante es que la Junta Ordinaria acordó, modificando asi el carácter del proyecto, grabar las láminas e imprimir las observaciones de Sarabia sobre la arquitectura de la Alhambra, porque "además de que esta obra daría crédito a la Academia y a la Nación, no duda que seria apreciable en toda la Europa" ${ }^{14}$. La importancia de la decisión adquiere una mayor significación debido al hecho de que se había tomado en un momento en el que aún no estaban realizados los dibujos correspondientes al Palacio de Carlos V. Es más, Sarabia consideraba necesario consultar los dibujos "originales" que creía que se conservaban en el archivo de la Alhambra, así como investigar "en uno de sus subterráneos" ya que existía la creencia de que en él se encontraban "las estatuas que se hicieron para su adorno: Que es natural esten alli las de Apolo y Venus del tamaño natural, y otras mas pequeñas de un Mercurio y Satiros, que ha tiempo se descubrieron» 15. Con el fin de copiar los planos y dibujar las estatuas, Sarabia solicitó permiso para poder entrar en el archivo e inspeccionar los subterráneos del Palacio de Carlos $V$, pero la Academia, aunque aprobó la petición, nunca dio las órdenes correspondientes.

El 19 de diciembre de 1762 se acordó grabar e imprimir la obra de Sarabia, áunque los dibujos del Palacio de Carlos $V$ no estuvieron termi-

14 Actas de la Junta Particular, del dieciocho de agosto de 1766. A.S.F., sign.: 121/3.

is Idem. En relación a esas esculturas y su búsqueda por Hermosilla véase el capítulo cuarto. 
nados hasta el cuatro de noviembre de 1763. Una vez concluidos se le indicó que colocase al comienzo de su obra una copia de la instrucción que la Academia le diera en diciembre de 1760.

La obra completa fue estudiada por la Junta General de la Academia el dieciocho de diciembre de 1763, coincidiendo con la toma de posesión, como Protector de la misma, del Marqués del Grimaldi, quien "creyendola digna de que la viese el Rey la llevó a S.M.». Carlos III la "vio con mucho gusto" y ordenó que algún miembro de la Academia realizase copias de los dos jarrones incluidos entre los dibujos de Sarabia con el fin de que pudieran servir "de modelos en la Fabrica de la Porcelana". La Junta Ordinaria tomó el acuerdo de encargar a José de Hermosilla la realización de las copias, lo que, por otra parte, constituye la primera toma de contacto de nuestro arquitecto con este proyecto, aunque fue de manera accidental y no supone, como se ha afirmado ${ }^{16}$, el inicio de su rectificación del trabajo de Sarabia, que no seria planteada hasta 1766 , coincidiendo con las primeras criticas al trabajo del pintor granadino, especialmente con respecto a los dibujos de arquitectura. Este hecho explica también la demora en dar comienzo al grabado de la obra, aunque se hubiera aprobado en 1762. Es más, en ese año los dos proyectos que la Academia consideraba prioritarios en su actividad editorial eran el Curso de Arquitectura de José de Castañeda y Diego de Villanueva ${ }^{17}$ y el grabado e impresión de la obra de Sarabia, suspendiendo, como consecuencia directa, la edición de la lconologia de Cesare Ripa que estaba traduciendo el escultor Felipe de Castro ${ }^{18}$.

Las objeciones que se pusieron a la obra de Sarabia en 1766 afectaban exclusivamente a los dibujos de arquitectura, tanto del palacio nazari como del palacio de Carlos V. Coincidiendo con el nombramiento de Hermosilla, Villanueva y Arnal para realizar de nuevo esos dibujos en Granada, la Academia repartió entre los grabadores el resto de los dibujos de inscripciones y motivos decorativos del palacio nazari, asi como las seis pinturas que contenian las de la Sala de los Reyes. Mientras los primeros estaban todos grabados en 1775 , aún cuando no fueran publi-

E. E. Rosenthal. El Palacio de Carlos V en Granada, obra citada, pag. 162

Sobre el Curso de Arquitectura de la Academia y sul edición fracasada veánse ahora F. Marias y A. Bustamante, "Sobre el "Curso de Arquitectura" de la Academia". en AA.VV. El Arte en tiempos de Carlos III. Madrid, 1989, pags. 151-159. Con la bibliografía anterior y J. Carpete Parrondo. Difusión de la Ciencia en la Espana Ilustrada. Madrid, 1989, que reproduce todas las estampas del curso conservadas en la Calcografía Nacional. págs. 178 . 214

${ }^{18}$ Actas de la Junta Particular. del siete de noviembre de 1762. A.S.F., sign.: 121/3 
cados hasta 1804 , de las pinturas sólo se ha conservado una estampa grabada por Manuel Salvador Carmona en $1767^{19}$, aunque nunca llegaria a ser incluida en las ediciones de la obra.

De cómo fueran los dibujos de arquitectura de Sarabia sólo podemos hacernos una idea por las criticas recibidas y por dos testimonios concretos como son un capitel de la Alhambra, incorporado por Hermosilla en la Lámina XVI de la primera parte de las Antigüedades Árabes de España (1787), y por un plano de las excavaciones que se habían realizado durante esos años en la Alcazaba Cadima o Vieja de Granada, en el Albaicin ${ }^{20}$. En todo caso, de sus conocimientos arquitectónicos nos quedan varios testimonios escritos $y$, sobre todo, parte del informe que acompañaba y estudiaba sus dibujos de la Alhambra de Granada para la Academia de San Fernando. Este informe manuscrito, titulado Descripcion Historica que comprehende la delineacion de los Reales Alcazares de la Ciudad de Granada, fue redactado por Sarabia entre 1761 y $1762^{21}$, y no ha gozado de excesiva fortuna. Aunque conocido y citado por autores como Bartolomé José Gallardo, Facundo Riaño, los hermanos Oliver Hurtado, M. Gómez Moreno, A. Gallego Burín, C. Viñes Millet o M. Sotomayor ${ }^{22}$, no ha sido puesto nunca en relación con la empresa académica de las "Antiguedades Arabes", al menos en la medida que su interés requiere. Sin embargo, la noticia de esa relación es antigua y fue publicada y utilizada su memoria a lo largo de las páginas de una obra muy conocida como son los Paseos por Granada y sus contornos, de J. Velázquez de Echevarría, interviniendo también en su redacción

${ }^{19}$ Véase al respecto el capitulo sexto. Sobre estas pinturas, depositadas por la Real Academia de Bellas Artes de San Fernando en el Museo de la Alhambra, vease J. Bermu. dez PAREJA, Pinturas sobre piel en la Alhambra de Granada. Granada, 1987.

${ }^{20}$ Aunque más adelante comentaré este asunto y sus implicaciones con la empresa de las Antiguedades Arabes, sobre el plano de Sarabia mencionado véanse A. FernandezGUERRA, "Inscripciones cristianas y antiguos monumentos del arte cristiano español", en El Arte en España, t. V, 1866, págs. 73-87 y M. GOMEz MORENo que lo reprodujo en «Monumentos arquitectónicos de la provincia de Granada", en Misceláneas. Historia. Arte, Arqueologia. Primera serie. La Antigüedad. Madrid, 1949, págs. 347-390. Durante su estancia en Granada, Juan de Villanueva dibujo también el lugar de esas excavaciones y, junto a los de Sarabia, se conservaban en la Academia de la Historia.

${ }_{21}$ El manuscrito se conserva, desgraciadamente incompleto, en la Biblioteca Nacional de Madrid: Diego Sanchez Sarabia, Descripcion Historica que comprehende la delineacion de los Reales Alcazares de la ciudad de Granada..., que de orden de Su Magestad y Real Academia de San Fernando a egecutado... Profesor de Matematicas y Academico de merito en dicha Real de San Fernando, sf., s.p., Sign.: Ms/13.188. La primera parte fue redactada en 1762 y la segunda al año siguiente.

* A. Gallego Burin, La Alhambra, obra citada, pág. 224, menciona la existencia de una copia del manuscrito en la Alhambra, sin embargo, los estudiosos posteriores se refieren siempre al manuscrito de la Biblioteca Nacional. 
Cristóbal de Medina Conde, editados en Granada en $1764^{23}$. El libro está planteado en forma de diálogo entre un "granadino" y un "forastero" ávido de curiosidades. Una de ellas, la plantea casi al comienzo solicitando al primero una explicación detallada del Palacio de Carlos $V$ en la Alhambra: "No pudiera yo hacerlo —responde el "granadino"-, si no huviera leido la bella, y circunstanciada descripcion, que hizo de esta Casa Real el infatigab!e estudio, destreza, y habilidad de D. Diego Sanchez Saravia, que de orden de la Academia de las tres Bellas Artes de San Fernando, de que es Individuo, trabajó, con los dibujos, y planta de ella; los que presento en Madrid y merecieron la Real Aprobacion, y de todos sus lllustres" ${ }^{24}$. Otras muchas noticias que proceden de Sarabia se encuentran esparcidas en diferentes páginas de la obra, incluso se hacen eco sus autores de la pretensión de aquél, no realizada, de localizar las estatuas "con que los Arabes tenian adornados sus Atrios, y palacios, en los Soterraneos de la Casa Real" ${ }^{25}$, lo que, por otra parte, nos da idea de la estrecha relación que estos personajes mantenian, de la que también es prueba elocuente su destacada participación en la falsificación de antigüedades realizada con motivo de las ya mencionadas excavaciones en la Alcazaba Cadima.

Otro texto importante para conocer la formación arquitectónica de nuestro pintor fue publicado precisamente por Medina Conde unos años antes, cuando Sarabia estaba realizando el encargo de la Academia de San Fernando. En sus Cartas del Sacristan de Pinos, publicadas en Granada entre 1761 y $1763^{26}$. Medina Conde realiza una defensa critica de las antigüedades descubiertas en la Alcazaba frente a las acusaciones de falsificación que sobre ellas habian pronunciado diferentes eruditos. Uno de los documentos que utiliza en favor de su argumentación es un texto de Sarabia, realizado en su calidad de "perito por la Arquitectura, y Dibujo, por la Real Junta de Excabaciones de esta Ciudad" y como "Comisionado" de la Academia de San Fernando "para la delineacion del Palacio Arabe". Publicado en la Carta III ${ }^{27}$, de 1762, tiene el enorme interés de ofrecer tanto su idea de la arquitectura en relación a la historia

23 J. Velazouez de Echevarria, Paseos por Granada, y sus contornos. Granada, 1764. 2 vols.

24 J. Velazouez de Echevarria. Paseos..., obra citada vol. I, pág. 9

25 Id. Paseos.... obra citada, vol. I. pág. 148.

${ }^{26}$ C. De Medina Conde y Herrera. Cartas del Sacristan de Pinos de la Puente... sobre los descubrimientos de la Alcazaba de Granada. I-IV, Granada. 1761-1763.

27 D. Sanchez Sarabia. "Dicho y deposición de... Nombrado perito por la Arquitectura. y Dibujo, por la Real Junta de Excabaciones de esta Ciudad", en C. DE MEDINA CONDE. Cartas del Sacristan de Pinos... obra citada, vol. III, 1762, págs 153-179. 
como las fuentes principales por él utilizadas para convertir la disciplina en un instrumento conceptual de carácter anticuario, diametralmente opuesto al desarrollado por Hermosilla cuando se enfrente con los edificios de la Alhambra y con la Mezquita de Córdoba.

Su propuesta es insólita en el debate arquitectónico español de la segunda mitad del siglo XVIII, tal como se ha descrito anteriormente. Es posible que el hecho de que Sarabia no sea un arquitecto profesional y que sus únicas actividades en este sentido se reduzcan a estudiar arquitecturas del pasado, y además de un carácter relativamente excepcional (la arquitectura islámica y la memoria de unos restos sobre cuya antigüedad existían numerosas dudas), hayan intervenido de manera decisiva en su forma de entender la arquitectura como un instrumento al servicio de la arqueologia y de los estudios anticuarios.

«Primeramente -escribe Sarabia-, siendo privativo en la Facultad de Arquitectura el reconocimiento de edificios, la antigüedad de sus fabricas, el modo de construirlas cada Nación aún en los tiempos más remotos, la pericia que se advierte en disponerlas, y operarlas, según las ruinas, que se manifiestan: Distinguir los fragmentos primitivos en semejantes Fabricas; y à què tiempos corresponden los demàs, que en lo successivo se fueron agregando, para su illustracion, reconocer á cual precepto de orden arquitectonica corresponden; advertir en el descombro, que ha ocultado por tantos siglos estos Monumentos, si insinuan esta Antiguedad en la conglutinación adquirida, ò efectos del peso con que la ha comprimido el recàlo de las aguas, y continuado trafico en la dilatada carrera de tantas edades" ${ }^{28}$.

Si el interés de este texto es enorme, no lo es menos la nota que incluye el final del párrafo en la que enumera las fuentes teóricas de su formación arquitectónica. En ella, los nombres de autores consultados resultan absolutamente convencionales en la cultura arquitectónica de la época. Pero lo más sugerente es el hecho de que los estudie en su calidad de "clasicos Authores, que instruyen en este assumpto de Antiguedad $"{ }^{29}$. Los tratados de arquitectura que cita los toma en consideración convencido de que en ellos estaba depositada la tradición arquitectónica de la Antigüedad, las normas que hacian comprensibles sus edificios y la constatación de que a partir de ellos podía articularse una historia de la arquitectura, imprescindible para enfrentar el estudio de los testimonios del pasado: Vitruvio, en la edición de D. Barbaro, Alberti

26 D. Sanchez Sarabia, "Dicho y deposición...", obra citada, pág. 155.
29 D. Sanchez Sarabia, obra citada, pag. 155. 
y Serlio son los textos mencionados, pero no bastan para una comprensión más exacta de la historia de las formas arquitectónicas, entendida también por Sarabia como una historia de la vida religiosa de la ciudad de Granada. En ese sentido cabe entender la mención de otra obra, significativa por su mismo título, como es la de P. Aringhi, Roma subterranea novissima, Roma, 1651.

Téngase en cuenta que estas referencias bibliográficas las menciona Sarabia en el contexto de su descripción de las antigüedades de la Alcazaba vieja de Granada, descubiertas por medio de la realización de cuevas y túneles en el subsuelo de esa zona de la ciudad. Además, la coincidencia, en esos hallazgos, de restos paganos y cristianos hacia imprescindible el recurso a textos como el de Aringhi, que era, por otra parte, una reelaboración del célebre trabajo de Antonio Bosio, Roma sotterranea. publicado en Roma en 1632, origen de una especifica arqueología cristiana ${ }^{30}$. El estudio científico de las catacumbas romanas, de los objetos, inscripciones y pinturas alli encontrados convirtieron la obra en una referencia ineludible, incluso cuando esa información documental era utilizada con un carácter apologético. De hecho, la fortuna de las estampas de la obra fue enorme, volviéndolas a publicar, con nuevos comentarios, Giovanni Bottari a mediados del siglo XVIII ${ }^{31}$, y, sobre todo, ejercieron una notable influencia en la forma de representación gráfica de los objetos e inscripciones descubiertos en la Alcazaba granadina, tanto en los dibujos conservados como en las estampas que para su divulgación se realizaron ${ }^{32}$.

Si en Granada, como en Roma, podían coincidir en un mismo lugar antigüedades paganas y cristianas, la oportunidad de confundir la arqueología y el valor religioso contemporáneo de las reliquias de los primeros cristianos se presentaba como inevitable. De hecho, cuando a mediados de la década de los años setenta del siglo XVIII esas antigüedades fueron condenadas a ser destruidas como falsas, son salvadas de entre ellas las que representaban la cruz o a Cristo: «... y quedaran reservadas - dice la sentencia condenatoria del seis de marzo de 1777- en poder del Yllmo. y muy Reverendo Arzobispo de esta Ciudad la Efigie de Nuestro Salbador puesta vajo el numero once, y las Cruces que se hallaron separadas de las Piezas falsas, por la veneración y reverencia que se

Sobre A. Bosio, vease G. WATAGHIN CANTINo, "Roma sotterranea. Appunti sulle origini dell' archeologia cristiana", en Ricerche di Storia dell'Arte, núm. 10. 1980, págs. 5-14. 1754

G. G. BotTARI, Sculture e Pitture sagre. estratte dai cimiterj di Roma. Roma, 1737.

32 Sobre este problema vease el capitulo tercero. 
debe à estos bultos de qualquiera fabrica que sean" ${ }^{33}$. Podría afirmarse que los instrumentos contrastados de la arqueologia clásica permitian proporcionar un carácter de autenticidad a otros testimonios del pasado. La arquitectura, en opinión de Sarabia, podía convertirse en la disciplina capaz de certificar la verdad de la historia en un sentido equiparable al del análisis filológico de las fuentes escritas o epigráficas.

Antes de comentar con mayor detenimiento las implicaciones que este complejo asunto de las antiguedades de la Alcazaba plantea, si quiero mencionar dos detalles que parecen confirmar algunas de las observaciones realizadas sobre el carácter que la intervención de Sarabia ofrece en relación tanto a esas excavaciones como a su descripción de la Alhambra para la Academia. La novedad de su planteamiento radica, como mantienen también otros implicados en los descubrimientos de la Alcazaba, en la consideración unitaria de la arqueología pagana y la cristiana, aun cuando fuera con un sentido apologético, manipulando los restos romanos como depositarios de la verdad de las inscripciones religiosas localizadas en el mismo lugar. En ese contexto, adquieren especial coherencia los libros mencionados anteriormente. En esta perspectiva no puede sorprender que un canónigo de la Abadia del Sacromonte de Granada, José Miguel Moreno, escribiese un libro en defensa de la autenticidad de los descubrimientos de la Alcazaba que tituló, significativamente, Granada subterranea. Para otros eruditos y anticuarios era precisamente esa coincidencia la que resultaba intolerable. Entre las criticas realizadas destaca la formulada en 1760 por Tomás Andrés de Guseme en su obra manuscrita Desconfianzas criticas sobre algunos Monumentos de Antiguedad que se suponen descubiertos en Granada ${ }^{34}$. En ella, ade-

${ }^{33}$ La documentación que cito sobre este complejo asunto se encuentra en un voluminoso legajo del Archivo General de Simancas, Gracia y Justicia, Legajo 1027. Un resumen de esa documentación puede verse en Razón del Juicio seguido en la Ciudad de Granada ante los Ilustrisimos Señores Don Manuel Doz. Presidente de su Real Chancilleria: Don Pedro Antonio Barroeta y Angel. Arzobispo que fue de esta Diocesis; y Don Antonio Jorge Galban. actual sucesor en la mitra, todos del consejo de Su Magestad: Contra varios falsificadores de escrituras públicas. monumentos sagrados. y profanos. caracteres. tradiciones, reliquias, y libros de supuesta antigüedad, Madrid, 1781.

${ }_{34}$ T. ANDRES DE GUSEME, Desconfianzas criticas sobre algunos Monumentos de Antiguedad que se suponen descubiertos en Granada en las Excabaciones de la Alcazaba desde el Año de 1753. 1760. El texto se conserva encuadernado con otros dos de Sarabia relativos al mismo asunto en la Biblioteca Nacional de Madrid, sign.: Ms/13.187. Con posterioridad. Guseme publicaria una obra muy elogiada. el Diccionario numismático general para la perfecta inteligencia de las medallas antiguas, sus signos, notas e inscripciones.... Madrid, 1773-1777. 6 vols. 
más de trazar una interesante descripción que pretende explicar el posible origen cultural del fenómeno, señalando que "estavan vivas las especies de lo que pasaba en Herculano, en Napoles, y aquel exemplo quizas movio alguna curiosidad para transplantar a España una imitación de tan singular recreación para los savios" ${ }^{35}$, plantea una seria critica, en el sentido comentado, considerando inverosímil que pudieran reunirse en un sólo lugar, "como en depósito", tantas y diferentes antigüedades tan poco "concordes" entre sí "y no puede disimularse el pensamiento de que todo se fue congregando de proposito ... en tiempos recientes» ${ }^{35}$.

La relación de Sarabia con las antigüedades de la Alcazaba coincidió con su trabajo para la Academia de San Fernando y, por ese motivo, las ideas que sobre la arquitectura enuncia en algunos de sus textos pueden servir para entender desde qué supuestos enfrenta el estudio de la Alhambra y sus edificios. Pero, además, hay que indicar que nuestro erudito pintor no tuvo recato alguno en incluir en su memoria explicativa de los palacios de la Alhambra las conclusiones que las antigüedades de la Alcazaba parecían poner en evidencia. Es, precisamente, esa intromisión la que hace necesario el estudio de la aventura arqueológica de las excavaciones mencionadas, también por el hecho de que sus defensores veian en el trabajo de Sarabia la oportunidad de confirmar institucionalmente el valor de sus descubrimientos. Como consecuencia directa de esa intromisión, Hermosilla, años más tarde, recibiría la recomendación expresa de la Academia de no mezclar esos "monumentos" con los árabes y cristianos de la Alhambra.

La memoria explicativa con la que Sarabia acompañaba los dibujos de la Alhambra encargados por la Academia de San Fernando se conserva, desgraciadamente, incompleta, fundamentalmente en la parte dedicada a la arquitectura árabe. Sin embargo, al menos hasta finales del siglo XIX debieron circular copias completas del manuscrito, siendo utilizado por otros autores. Además de las referencias contenidas en la obra de Echevarria y Medina Conde, todavia, en 1842, José Garcia Hidalgo en su lliberia ó Granada, publicada en la misma ciudad ${ }^{36}$, confesaba haberse servido del texto de Sarabia en sus descripciones arquitectónicas. Pero cuando en $1865 \mathrm{~J}$. F. Riaño publica su estudio sobre las des-

35 T. AndRes de GuSEme, Desconfianzas criticas, obra citada, s.p.

${ }^{36} \mathrm{~J}$. Hidalgo Morales, lliberia o Granada, Granada, 1848, 2. edición, pág. 247. 
cripciones antiguas y modernas de la Alhambra menciona sólo el manuscrito que conocemos de la Biblioteca Nacional ${ }^{37}$.

El informe de Sarabia, como sus dibujos, está dividido en dos partes. una dedicada a la arquitectura árabe y la otra a la cristiana en las construcciones de la Alhambra. Sin embargo, introduce, tanto al comienzo como al final de la obra, una serie de observaciones directamente derivadas de los descubrimientos realizados en las excavaciones de la Alcazaba, con el fin de trazar una historia fabulosa sobre el origen de la propia ciudad de Granada antes del asentamiento en ella de sus habitantes islámicos, privilegiando sobre todo la memoria de la antigüedad clásica y cristiana. Esos textos se plantean, además, como una recuperación de las tradiciones religiosas surgidas a finales del siglo XVI con los descubrimientos de las reliquias y libros plúmbeos del Sacromonte de Granada, del mismo modo que las antigüedades encontradas en las excavaciones de la Alcazaba servían para confirmar su autenticidad: la invención de un lugar sagrado, el Sacromonte, era asi legitimada por la existencia de un lugar antiguo, la Alcazaba vieja. Es más, previamente a las certidumbres proporcionadas por los restos arqueológicos, la vinculación entre ambos lugares había sido anunciada, según confesión de uno de los principales implicados en las excavaciones de la Alcazaba, Juan de Flores, por Luis Francisco de Viana, abad del Sacromonte, que le aseguró que "desde aquel sitio al Monte Santo habian visto de noche Procesiones de personas vestidas de blanco con luces, lo que indicava que alli abría otras Minas donde se encontrarian los Libros del Concilio lliberitano, Cuerpos de muchos Martires y todo lo que no se avia encontrado en el Monte Santo" ${ }^{38}$.

La descripción de la Alhambra comienza a hacerla Sarabia destacando su situación al lado de la "antigua Ylliberia» sobre la que se alzaba la Alcazaba vieja, en el actual barrio del Albayzin, señalando cómo muchas de las construcciones islámicas utilizaron restos de fábricas "gentilicas" y de "antiquisimos Españoles", incluidas lápidas e inscripciones epigráficas. La fortaleza nazari se levanta, según nuestro autor, sobre el monte "Capitolino", ya que, como escribiría un poco después

J. F. RIANo. "La Alhambra. Estudio crítico de las descripciones antiguas y modernas del palacio arabe", en Revista de España, t. XCVII. nums. 385 y 386, 1884, págs. 186-202. El manuscrito procede, como senala el mismo Riaño. de la Biblioteca del Marques de la Romana: véase al respecto. Catálogo de la Biblioteca del Excmo. Sr. D. Fedro Caro y Sureda. Marques de la Romana. Madrid, 1865.

${ }^{36}$ Contesión de Juan de Flores ante el presidente de la Real Chancilleria de Granada. José Manuel de Vargas, el veintiuno de junio de 1774. A.G.S.. Gracia y Justicia, Leg. 1.027. 
Echevarria, Granada "está colocada en siete collados, como Roma" ${ }^{39}$. En el texto de Sarabia aparecen nuevamente articulados los esfuerzos historiográficos que desde el siglo XVI habian pretendido dotar a Granada de un pasado privilegiado, anterior a la presencia islámica en la ciudad, tanto desde el punto de vista religioso como desde el de la presencia de una antigüedad clásica. Asi en el Capitolio granadino "estaba el suntuoso templo de Nata Diosa Patricia, y de singular veneración para los Ylliberitanos, y la recamara de los Dioses donde se conserbaban todas sus efigies, o estatuas de las Deidades", lo que, además, vendria confirmado por el Canon 59 del célebre Concilio Ylliberitano, que ordenaba que ningún cristiano "suba al Capitolio a sacrificar â Ydolo, ô â ber los sacrificios" ${ }^{40}$. Todas estas afirmaciones encontraban su confirmación en muchos de los recientes hallazgos de la Alcazaba, convirtiendose también en ejemplo de aplicación práctica de su propio concepto de la arquitectura en relación al estudio de la memoria del pasado, una de cuyas funciones, como ya se ha mencionado, era la de "distinguir los fragmentos primitivos en semejantes fábricas; y à què tiempos corresponden los demà, que en lo sucesivo se fueron agregando".

Otras muchas noticias semejantes se hayan esparcidas a lo largo de su memoria, pero ahora interesa destacar sobre todo una serie de observaciones que permiten profundizar en los supuestos desde los que estudia la misma historia de la arquitectura entendida como correlato de los orígenes religiosos e históricos de la propia ciudad de Granada. La presencia, en algunos muros de la fortaleza de la Alhambra, de restos constructivos de "nuestros antiquisimos Españoles", cambiando la atribución tradicional de "obra fenicia", y "Gentilicos", no sólo eran motivo para asegurar la antigüedad del lugar sino también para explicar la preferencia de "los Reyes Moros" por el mismo. Echevarría llegaría a escribir al respecto: "Nada me parece exgeración, pues aún desde aqui se conoce tuvieron fundamento los moros para creerla su Paraíso Terrenal, y desean su restauración, como la de Jerusalén los Christianos" "

La Alhambra, "magnificencia" y "ornato" de la ciudad, iba a convertirse en excusa para narrar el mismo origen de la Arquitectura con argumentos ya entonces desplazados por los estudios arqueológicos y por la misma teoria de la arquitectura. "Es tan antigua la facultad de la Arquitectura -escribe Sarabia en su memoria - que en mi dictamen, trae su

\footnotetext{
${ }^{39}$ J. oe Echevarria, Paseos por Granada, obra citada, vol. 1. pág. 3.

40 Un extracto del texto de Sarabia puede verse en el Apendice

41 J. DE Echevarria, Paseos por Granada, obra citada, vol. I, pág. 4.
} 
ôrigen (prescindiendo de la fabrica del Universo, de quien es Dios el Soverano Artífice) desde el primer Hombre" que, expulsado del Paraiso, "quedó a su cuidado, buscar refugio... ô en los concabos de una cueba, ö en el cubierto de alguna choza". Si enunciada asi, la teoria sobre el origen de la arquitectura no parecia diferir mucho de los contemporáneos planteamientos sobre el modelo de la arquitectura en la cabaña primitiva, ya fuera entendida desde una perspectiva vitruviana o racionalista ${ }^{42}$, sin embargo, la diferencia se establecia en el desarrollo posterior de la argumentación al completar la narración ateniéndose a la Biblia, continuando asi una secular tradición que, desde Villalpando a Kircher, habia gozado de una particular atención desde el Ranacimiento. Cabe señalar, en este momento, que Echevarría y Conde, de cuya estrecha relación con Sarabia poseemos sobradas evidencias, no tenian inconveniente en afirmar, en sus Paseos por Granada, por boca del "granadino", que todo lo que sabian de antigüedades lo habian aprendido de Kircher. Lo que parecian desconocer es que fue la intervención de Athanasius Kircher una de las decisivas en la condena de los libros plúmbeos del Sacromonte, llevados a Roma para su estudio, en el Breve promulgado por Inocencio XI en 1682, casi cien años después de su descubrimiento.

La descripción de los origenes de la arquitectura que hace Sarabia le permitia, además, establecer una relación directa entre Granada y la magnificencia y sabiduria que encerraban los edificios descritos en la Biblia, especialmente en el Génesis, pero también establecer un fundamento arqueológico para explicar las inscripciones "de antiguos caracteres" que aparecian en las excavaciones de la Alcazaba. El esquema básico de lo narrado por Sarabia habia sido estudiado por Kircher en dos obras fundamentales, Arca Noë, publicada en Amsterdam en 1675 y dedicada a Carlos II, y Turris Babel, publicada cuatro años después en la misma ciudad ${ }^{43}$.

Sarabia señala que Adán transmitió los primeros conocimientos arquitectónicos, pero indica cómo Caín, fundador de la primera ciudad, Henoc, ciudad de los gigantes, estableció el punto de partida de la historia de la arquitectura, porque en su "costruccion ya ha de concurrir eleccion de sitio, distribucion de Edificios en simetria, fortificacion y magnifizencia decorosa...». El siguiente hito fundamental no podía ser otro que la cons-

Sobre este problema vease J. Rrkwert. La casa de Adán en el Paraiso, Barcelona.

43 Sobre Kircher veanse RivoseCCHI. V., Esotismo in Roma barocca. Studi sul padre Kircher. Roma. 1982; J. GodwIN, Athanasius. La busqueda del saber de la Antiguedad, San Lorenzo de El Escorial. 1986. 
trucción del Arca por Noé: "Comienza el Mundo con un Arquitecto, sigue el aumento de los vivientes, hasta, que la maldad corrompió en un todo la naturaleza y un Arquitecto y su familia es el que se preserba del absoluto general naufragio en un edificio, efectos de esta facultad de donde se hace manifiesto probiene la cultura de esta ciencia despues del Dilubio".

Para resumir, Sarabia continúa su historia a través de Cam, Nemrod, arquitecto de la Torre de Babel, hasta los egipcios, "tan superiores en la magnifica suntuosidad de sus obras de Arquitectura". Herederos directos de su sabiduría arquitectónica, los "fenices» serían utilizados como arquitectos por Salomón para la construcción de su Templo. Y serian estos últimos los primeros arquitectos de Granada: "Hallanse en esta Ciudad barios Monumentos y ruinas de Edificios, con la tradicion imbariable de ser fragmentos respectables de antiquissimos fenices Arabes, que binieron con Ôsiris Rey de Egipto, y su hijo Hercules. Esto tiene mucha probabilidad, por las Lapidas y bronzes con inscripciones antiquissimas de caracteres de rara estrañeza, que se an encontrado en las excabaciones de la Alcazaba en obsequio del culto de estos Heroes".

La referencia al Hércules egipcio, fundador de dinastias, naciones y ciudades por toda Europa, no podía faltar en la cronología fabulosa que sobre el origen de la arquitectura y de la ciudad de Granada estaba construyendo Sarabia, siguierido en esto una tradición legendaria desde el siglo XVI. La sabiduría antigua pasaba asi, sin intermediarios grecorromanos, a España. La invención del Hércules egipcio fue obra de Annio da Viterbo en su polémica e influyente Commentaria... super opera diversorum auctorum de antiquitatibus loquentibus, publicada en Roma en $1498^{44}$. Los textos reunidos procedian, supuestamente, de obras inéditas de antiguos autores, y constituian una suerte de integración del Antiguo Testamento con las culturas anteriores al mundo grecorromano. De esta manera, pueblos, ciudades, dinastias y familias podian encontrar una ascendencia mítica entre sus antepasados, con independencia de los mitos de la cultura clásica. El esfuerzo mayor de Annio estuvo dedicado, sin

4. Sobre la figura de ese gran falsario del Renacimiento que fue $\mathrm{A}$. da Viterbo véanse R. WEISS, "Traccia per una biografia di Annio da Viterbo", en Italia Medioevale e Umanistica. V. 1962. pags. 425-441: G. Baffioni E P. Mattiangeli. Annio da Viterbo. Documenti e ricerche. Roma, 1981. y G. MOROLLI, "Vetus Etruria". Florencia, 1985. En relación a Annio da Viterbo y su "invención" del Hércules egipcio véase Marc-René Jung, Hercule dans la litteratue française du xvf siecle. De lHercule courtois a l'Hercule Baroque. Ginebra, 1966. sobre todo, págs. 42-72. La presencia, sin embargo, de menciones al Hercules egipcio en textos griegos verdaderos es comentada por E. WIND, Los misterios paganos del Renacimiento. Barcelona, 1972. pág. 255 
duda, al mundo etrusco, pero no olvidó a los "españoles». De hecho, la obra está dedicada a los Reyes Católicos y él mismo fue Maestro del Sacro Palacio durante el pontificado de Alejandro VI Borgia ${ }^{45}$. El libro XII de sus Commentaria lleva por titulo De primis temporibus et XXIV regibus Hispaniae et eius antiquitate. Del mismo modo que el pueblo etrusco es, como el hebreo, un pueblo elegido, siendo Jano-Noé su fundador, los españoles participarian de un pasado privilegiado semejante al ser Hércules hijo de Osiris y nieto de Cam.

Desde Florián de Ocampo a los más importantes historiadores de Granada desde el siglo XVI, la referencia a Hercules egipcio no fue infrecuente, pero lo que me interesa destacar ahora es cómo Sarabia estaba convencido de poder confirmar esa leyenda falsa con testimonios arquitectónicos cuyo valor fundamental no era sino "su rara solidez", venerables vestigios que "han podido triunfar del tiempo", pasando después a describir sus métodos de construcción y los lugares de Granada en los que aún podian observarse.

Precisamente Kircher, en su Turris Babel, al comparar las maravillas del mundo antiguo entre si $y$, sobre todo, las egipcias con las griegas, señala que estas últimas no han podido permanecer integras, mientras que las primeras parecen haber vencido al tiempo, atributo fundamental de las maravillas: la Torre de Babel, en este contexto, se convertía en símbolo de la arrogancia humana y su destrucción en consecuencia lógica del desafio tanto a Dios como a las leyes de la naturaleza. Testimonio de su existencia efímera seria un ladrillo que Kircher conservaba en su Museo del Colegio Romano y herencia del castigo divino la confusión de las lenguas ${ }^{46}$.

Varios restos arqueológicos de esa época fabulosa de los "fenices" describe Sarabia a continuación, vinculando muchos de ellos a sucesos religiosos en la tradición del Sacromonte. En las excavaciones de la Alcazaba apareció un muro de esas características en el templo "donde se celebró el Concilio Illiberitano, donde se an encontrado distintos bestigios; unos de este primitivo ôrigen, y otros posteriores, con que en los subzesivo fueron ilustrando los Gentiles este edificio con Arquitectura ya de los

bas relaciones entre Annio da Viterbo y Alejandro VI. a proposito del programa iconográfico del Apartamento Borgia en el Vaticano. han sido estudiadas recientemente por P. PEDRAZA. "Pacis Cultor. Apuntes para una interpretacion del Apartamento Borgia del Vaticano". en Ephialte. núm. 1. 1989. págs. 125-160. Véase tambien el anterior estudio de F. SAXL, "El Apartamento Borgia". en La vida de las imagenes, 1989. págs. 160-172.

$\because 6$ A. KIRCHER. Turris Babel, obra citada, pag. 95. Sobre este problema vease el estudio de V. RIOSECCHI, Esotismo in Toma Barocca... obra citada. págs. 108 y ss. 
cinco ôrdenes". También la torre de la iglesia de San José la creía de esa época ${ }^{47}$, asi como los materiales empleados en la iglesia de San Cristóbal, "que antes era Mezquita, y esta, la reedificaron los Moros sobre los cimientos y ruinas de un Edificio suntuoso fenicio...".

Estos mudos testigos adquieren, en el estudio de Sarabia, una elocuencia inesperada, convenciéndole de que "la Arquitectura que usaron en España los Moros, trae su ôrigen de los fenices, y Arabes antiquissimos; y esto alude también con el nombre, que conserban las Cupulas, y Arcos apuntados angulares que formaban de labirinto llamadas salomónicas, ô Mosaycas... En lo que desbarraron los Moros, fue en no Ymitar â aquellos primitibos Arabes en la solidez de sus Muros". Se cierra asi, simbólicamente, el vinculo de la arquitectura islámica con la tradición bíblica sobre el origen de la arquitectura, con la sabiduria antigua. La arquitectura de los árabes, como su lengua, no sería sino consecuencia de aquella confusión de Babel. Su pericia y magisterio son indudables, sólo la distancia, religiosa e histórica, habian ocasionado el mayor defecto de su arquitectura, su «fragilidad».

De esta forma Sarabia podía iniciar el estudio de la Alhambra nazari sin establecer comparaciones o juicios con los modelos clásicos de la arquitectura grecorromana. Su mismo origen simbólico permitía analizar la arquitectura islámica de manera autónoma, no como degradación o desconocimiento de las leyes de la arquitectura clásica, sino como dialecto de un conocimiento antiguo, de una antigüedad sancionada a la vez por la Biblia y la arqueologia. Es más discute las observaciones realizadas sobre la arquitectura islámica por Francisco Ruano en su Historia General de Córdoba (1762), que señala que "los Artifices Arabes procuraron imitar en sus obras las labores Romanas. Mas por quanto ignoraban las sutilezas de la Theorica y las proporciones geometricas usadas de los Griegos y Romanos, executaban con poca elegancia, y Magestad sus obras quando declinaban de sus primores Mosaycos, en los quales fueron eminentes" ${ }^{48}$. Obviamente, Sarabia no podia aceptar una conclusión semejante: "no sè en que lo funda pues no è hallado en todas sus

47 Sobre el tipo de aparejo de estos restos véase M. Gomez Moreno, El arte arabe español hasta los almohades. Arte mozarabe. Ars Hispaniae, vol. III, Madrid, 1951. pags. 172-179.

${ }^{48}$ F. Ruano, Historia general de Córdoba. Córdoba, 1762, t. I. pag. 273. Con posterioridad. discute Sarabia las observaciones de Ruano en relación al origen y disposición romanas de la Mezquita de Córdoba, señalando que cree que el edificio "es planta, direccion ê idea Arabe. Concediendo solo que muchas de sus colunas y capiteles son fragmentos de Edificio. ó Edificios Romanos, ó ya aprobechandose de ellas como constata en su proporcion (que lo dudo) ô arreglandolas a su estilo». 
obras resquicio, que insinue tal casta, y estoy en que erró en este dictamen».

Desgraciadamente, como ya se ha visto, la descripción concreta de la arquitectura nazari de la Alhambra no aparece en el manuscrito conservado, del mismo modo que tampoco se encuentran los dibujos correspondientes que realizó Sarabia entre los custodiados en la Academia de San Fernando y que coinciden con los sustituidos por Hermosilla, Villanueva y Arnal, tanto del palacio árabe como del de Carlos V. En cualquier caso, su idea de la arquitectura parece quedar evidenciada a través de los testimonios comentados hasta ahora.

Particular interés tiene, sin embargo, la segunda parte de su informe sobre la Alhambra en la que se describe y comenta el Palacio de Carlos $V^{49}$. La obra de Machuca, aunque Sarabia atribuye erróneamente el proyecto a Alonso de Berruguete ${ }^{50}$, es entendida en su texto como el colofón ideal a un recinto sagrado y simbólico, resuelto tipológica y formalmente con un edificio que plantea, con todas sus contradicciones, la perfección de un modelo clásico. La Alhambra se convierte asi en uno de los más atractivos ejemplos de la historia de la arquitectura según sus fundamentos biblicos: arquitectura revelada y tradición clásica no parecen contradecirse en opinión de Sarabia. La colisión de lenguajes, la intromisión cristiana en el recinto islámico, son contemplados como la forma más adecuada de cerrar simbólicamente un lugar cuyo carácter profano no puede ocultar su mítica sacralidad. Incluso el sentido civil y triunfal del nuevo palacio es mitigado por Sarabia otorgandole los atributos de distanciamiento propios de una villa antigua: "Finalmente -escribe en su memoria - el Cesar determinó la execuzion de la ôbra comenzando a dar disposiziciones para la atraccion de Artifices de que se formasen diseños, con animo de que residiese en esta ciudad la Corte, que no tubo efecto por la conveniencia grande de que los Reyes residan en medio de sus reynos... eligiendo este Real Sitio para descanso de sus cuidados y retiro del mundo, a que despues su animo religioso y desengañado, lo inclinó al paraxe del Monasterio de Yuste». El problema planteado en este párrafo por Sarabia resulta de una actualidad sorprendente si recordamos las recientes polémicas sobre la verosimilitud de la inter-

${ }^{49}$ A pesar de las numerosas noticias documentales y comentarios que proporciona este interesantísimo texto, no ha sido utilizado en ninguno de los recientes estudios sobre el Palacio y el Pilar de Carlos $V$ en la Alhambra.

so Sobre este problema véase E. E. Rosenthal, El palacio de Carlos V, obra citada, pág. 11. 
pretación de la obra de Machuca más como una villa que como un palacio y la implicación directa de ese aspecto en la propia configuración tipológica y formal del edificio, hasta el punto poder reconocer en esa "diferencia" una importancia decisiva en la misma génesis del proyecto ${ }^{51}$.

La parte del informe de Sarabia dedicada al palacio de Carlos V comienza con una descripción de su aspecto inacabado y de la imposibilidad de localizar los planos originales del palacio, "que siempre hize Juicio estarian en el Archivo de esta Real Fortaleza", pero que no pudo consultar. A continuación se hace eco de la "voz común" que mantenia que en los subterráneos del palacio existian esculturas, tanto antiguas como modernas, destinadas a la decoración del edificio. Después comenta los motivos que indujeron a Carlos $V$ a construir el edificio, describiendo previamente las reparaciones y diferentes intervenciones que en la fortaleza y palacio nazaries hicieron los Reyes Católicos. La llegada de Carlos V con Isabel de Portugal en junio de 1526 a Granada es narrada con tintes retóricos, basados en fuentes impresas de los siglos XVI y XVII: "Aposentose el Señor Emperador en el Alhambra donde aquella noche gustó mucho de ver desde las ventanas de la Torre de Comares, yluminada la Ciudad emula del firmamento.

Ôtro dia madrugó a ver la fuerza del Alhambra y le admiró el artificio y costa de los edificios Arabes: La curiosidad de las fuentes, y la abundancia de aguas en sitio tan alto...". Resume Sarabia las intenciones de Carlos V señalando que pretendió aumentar la comodidad del palacio nazari "al estilo castellano" -es muy revelador que no mencione en absoluto la denominación "a lo romano", diriase que tan apropiada al asunto ${ }^{52}$ - La fábrica del nuevo edificio no debia manifestar tan sólo «su

51 En relación a este polemico asunto, véanse las diferentes posiciones que, sobre las consecuencias disciplinares e historiográficas de la consideración del edificio de Machuca entendido como "villa". han mantenido E. E. ROSENTHAL, El Palacio de Carlos V. obra citada; id.. "E| programa iconográfico-arquitectónico del palacio de Carlos $V$ en Granada", en AA. VV.. Arquitectura imperial. Granada, 1988, pags. 159-177. y M. TAFuRI, «\|l Palazzo di Carlo V a Granada: architettura "a lo romano" e iconografia imperiale", en Ricerche di Storia dellarte. núm. 32, 1987, pags. 4-26. Una opinión contraria a la idea de entender el palacio como villa puede verse en F. CHECA, Carlos $V$ y la imagen del héroe en el Renacimiento. Madrid, 1987, págs. 56 y ss.

${ }_{52}$ Recientemente M. TAfURI proponia una muy sugerente hipótesis de lectura en el sentido de entender el Palacio de Carlos $V$ como una manifestación antirromana: «... lo que no es realizado en Roma parece ser realizado en la peninsula iberica. Es evidente la voluntad de dotar al Palacio de significados resumibles en una traslatio referida al "centro" politico y cultural de la Roma pontificia, recientemente humillado con el Saco... la legitimación del poder busca precedentes especificos en lo antiguo y rivaliza con la centralidad de 
generoso Magnanimo Espíritu», sino que además era "combeniente para freno del örgulio y doblado animo de los Moriscos...» y, por eso mismo, el lenguaje arquitectónico debia ser tan absolutamente distinto al del palacio nazari y se "discerniese la diferencia de una y otra avitación".

Despues de la explicación de los motivos que habian inducido a Carlos $\mathrm{V}$ a construir el palacio, Sarabia da noticia del autor de las trazas y de sus sucesivos arquitectos, señalando que tanto las trazas como el inicio de los cimientos se hicieron estando en Granada "el Cesar», Io que parece no coincidir con los testimonios documentales conservados ${ }^{53}$. Siguiendo, como posteriormente tambien haria Hermosilla, a Palomino, Sarabia atribuye las trazas a Alonso de Berruguete, retomando una tradición que se remonta a Juan de Butrón, que, en 1626, asi lo afirmaba ${ }^{54}$. Segun nuestro autor, al abandonar Carlos $V$ Granada, "quedo por Theniente de Arquitecto Mayor el que en dicho Arte lo era grande, Pintor, y Esculptor el Memorable Machuca, Discipulo de Raphael de Urbina" ${ }^{55}$. Señala también Sarabia que le sucedió en el cargo Diego de Siloé, haciéndose eco de una noticia proporcionada por Juan de Arfe en su Varia Commensuración para la esculptura y architectura, publicada en Sevilla en 1585, aunque citada por una desconocida edición anterior de $1581^{56}$.

Sarabia menciona también las fuentes de financiación para las obras de la Alhambra asi como las reparaciones y obras nuevas en distintas partes de la fortaleza, siguiendo en esto, como en otros muchos asuntos las obras de Francisco Bermúdez de Pedraza ${ }^{57}$, escribiendo: "Admite también el Dr. Bermudez, que se regulaba la obra para su conclusión en mas de quinientos mil ducados, y haziendo Juicio que le falta otro

Roma. Todo ello, no en una capital real. sino en una capital simbólica: la Granada consagrada como lugar de un nuevo inicio de los tiempos» en "ll Palazzo di Carlo V". obra citada, pág. 21. El supuesto "estilo castellano" con el que define SARABiA el palacio de Machuca podria interpretarse en un sentido parecido, con todas las cautelas necesarias

${ }^{53}$ Sobre los aspectos de la construcción del palacio, vease E. E. Rosentral. El Palacio de Carlos V.... obra citada, especialmente el capitulo primero.

${ }^{54}$ En relación a la atribución a $A$. DE Berruguete, véase $E$. E. Rosenthal, El Palacio de Carlos V.... obra citada, pág. 11.

${ }_{55}$ Sobre la formación de Machuca en Italia las polemicas no han cesado hasta tiempos recientes, véase el resumen de E. E. Rosenthal, El Palacio de Carlos V.... obra citada. págs. 12 y ss. con la bibliografía anterior, y también N. DACOS, "Pedro Machuca en Italie», en Scritti di Storia dell'arte in onore di Federico Zeri, Milan, 1984, págs. 332-361.

${ }^{56}$ Sobre las ediciones de Juan de Arfe, vease el estudio de A. BONEt CORrEA, "Juan de Arfe y Villafañe: "Escultor de oro y plata" y tratadista", en la edición facsimii de Varia Commensuracion para la esculptura y architectura. Madrid, 1974, págs. 9-64.

${ }^{57}$ Las obras que cita de Bermudez de Pedraza son antigüedades y excelencias de Granada, Granada. 1608 y, sobre todo. Historia eclesiástica. Principios y progresos de la ciudad y religión católica de Granada. Granada, 1638. De esta última hay edición facsimil reciente. con estudio de I. Henares Cuellar, Granada. 1989. 
cuerpo, y las quatro torres, gran costo de balcones, y demas regeria, solerías $\&^{a}$, y lo que insinua el abanze de un arco por donde habia de seguir obra, me impone mas en el Dictamen de que quedaron costeadas las estatuas que habian de ocupar el todo de los nichos situados en este Palacio». El texto tiene una importancia sorprendente ya que nos describe un palacio por terminar que es muy distinto del que conocemos tanto por los planos conservados del siglo xvi como por la misma obra construida. Cuando Sarabia escribe esto el palacio tiene, como sabemos, dos plantas y, según sus noticias, le falta aún una más y cuatro torres en las esquinas. Se trata de una tipología que presenta una extraordinaria semejanza con "La casa del principe ilustrísimo para construir en el campo" que Serlio dibujara en su inédito y manuscrito Sexto Libro ${ }^{58}$, M. Rosci ya puso en relación ese proyecto y el palacio de Carios $V$ al publicar el manuscrito de Serlio ${ }^{59}$, aunque sabemos que este es posterior a las trazas de Machuca y presenta, además, la diferencia de incluir tres plantas y cuatro torres en las esquinas, exactamente igual al que describe Sarabia en su texto. Por sus propias afirmaciones, conocemos que este último no pudo ver los dibujos originales del palacio granadino, luego su fuente figurativa debió ser una maqueta que se conservaba en la Alhambra y que mencionan tanto Llaguno como Velázquez de Echevarria ${ }^{60}$. Que se trate de la maqueta original es desde luego cuestionable, ya que la descripción de un edificio con torres en las esquinas no puede identificarse con el proyecto de Machuca. Tanto Echevarría como Sarabia deben referirse a la misma maqueta, sabiendo, además, que este último confesaba haber utilizado el informe de aquél.

Lo que, sin embargo, si parece quedar claro es que esta maqueta no es, como ha supuesto Rosenthal, la realizada en tiempos de Machuca ${ }^{61}$. Debe tratarse de la realizada por Bartolomé Fernández Lechuga en 1625 con el fin de dar un nuevo y definitivo impulso a las obras

58 El manuscrito fue publicado, en sus dos copias conocidas, por M. Rosci, // trattato di architettura di Sebastiano Serlio. Milan. 1966 y M. N. Rosenfeld, Sebastiano Serlio On Domestic Architecture. Nueva York, 1978. Recientemente también ha sido editado en España. con su traducción castellana, y con estudio de C. Sambricio, "La fortuna de Sebastiano Serlio", en S. SERLIO, Todas las obras de arquitectura y perspectiva. Oviedo, 1986. En general, sobre el tratado y las obras de Serlio, véase C. THOENES (ed.), Sebastiano Serlio. Milan, 1989.

59 M. Roscl, /l trattato..., obra citada, pág. 73.

60 Sobre la maqueta del palacio véase lo estudiado por E. E. RosenthaL, El Palacio de Carlos V..., obra citada, págs. 43-44, donde menciona las referencias que hacen E. LLA. GUNO. Noticias de los arquitectos y arquitectura de España desde su restauracion, Madrid. 1829, t. I, pág. 220, y J. VelazQuez de ECheVarRia, Paseos por Granada..., obra citada, t. I. pág. 28.

6! Ibid., pág. 44, donde señala: "Al parecer sobrevivió hasta mediados del siglo XVIII". 
del palacio, pero cambiando sustancialmente la imagen misma del edificio, proyectando una tipologia arquitectónica que, más que completar, negaba la permanencia de lo ya construido. En vez de una ampliación se trataria de un nuevo edificio que absorbe, humillándolo, al anterior. El palacio de Machuca pasaría de ser una orgullosa excepción en la tradición tipológica de los palacios reales españoles desde el siglo XVI, a convertirse en el elemento final de una serie, configurando asi una insólita homogeneidad en las casas del Rey. También, desde esta perspectiva, adquiere mayor interés la observación de Sarabia, ya mencionada, de que Carlos V proyectó una construcción "al estilo castellano».

La transformación propuesta por Lechuga tiene, sin duda, una enorme importancia, aunque no es este el momento de analizarla en todas sus implicaciones. Sí quiero recordar, sin embargo, que su proyecto, seis dibujos y una maqueta, junto con las reformas planteadas en 1580 por Juan de Herrera y las de Francisco de Potes, de 1620, ambas de mucha menor entidad, fue sometido al juicio de Juan Gómez de Mora en Madrid a finales de 1625 . En su informe, no consideró conveniente el aumento del palacio con las torres - Goméz sólo habla de dos torres en la fachada principal-, pero se desprende del mismo que no le disgustó el proyecto de Bartolomé Lechuga. Razones económicas y supuestamente constructivas - la obra realizada no podría soportar el peso de las torres, según Gómez- aconsejaron una resolución de carácter eminentemente práctico que, además, añadia la ventaja de no alterar las intenciones primitivas ${ }^{62}$. Es posible que nunca como a proposito de esta maqueta sea tan oportuno recordar la advertencia que, sobre el seductor engaño que ocasionaban estos modelos tridimensionales, hiciera, en 1615, V. Scamozzi: "I modelli sono - escribe en su ldea dell'Architettura universale- a simiglianza di piccoli uccelli, i quali per (sé stessi) non si discernono bene se sono maschi o femmine, ma poi fatti grandicelli si conoscono per aquile o per corvi, e perciò è anco assai facile cosa che $i$ padroni siano ingannati sotto coperta di modelli».

El informe de Sarabia continúa recordando la visita que a la Alhambra hiciera, en 1624, Felipe IV, quien por cierto no pudo alojarse en el palacio nuevo, escribiendo que "se recreaba particularmente con la vista de la Sala de Comares diziendo su Magestad que alli no podia haber melancolia". Pero a la visita real a la que nuestro autor concedía más

62 Sobre el proyecto de Bartolomé Fernández Lechuga, véase E. E. RosentHAL. El Palacio de Carlos $V$.... obra citada. págs. 153 y ss. En relación a las ideas de Gómez Mora sobre la arquitectura palaciega, vease V. Tovar, Juan Gomez de Mora (1568-1648). Madrid, 1986 . 
importancia era sin duda a la realizada por Felipe $V$ en 1730, y no tanto por las reparaciones que se hicieron en el palacio de Carlos $V$ con ese motivo, sino por la presencia del futuro Fernando VI, del que cuenta la anécdota, enormemente significativa al menos para Sarabia, de que después de recorrer con detenimiento el palacio "se encaminó S.M. hazia las gradas del Atrio principal de la Yglesia Parroquial, donde habiendo subido y tomado en el distancia competente estubo atendiendo el todo de la obra con harto gusto... Dixo su Magestad con juvilo, esta obra è de mi Abuelo Carlos $V$ y inclinando la mano al pecho con repetizión. prorrumpio S.M. Yo la he de acabar, yo la he de acabar...". Una prueba del interés de Fernando VI por la Alhambra la habria de proporcionar, precisamente, la iniciativa de la Academia de San Fernando para dibujar y grabar los palacios e inscripciones de la fortaleza. Por otra parte, la idea de terminar el palacio de Carlos $V$ parecia seguir viva en Granada durante estos años. De hecho, cuando Hermosilla llegue, unos años después, a la ciudad, comentará cómo se pensaba que el verdadero motivo de su presencia no era otro sino el de terminar el edificio de Machuca.

Además de una prolija descripción sobre el programa iconográfico y las virtudes arquitectónicas del pilar de Carlos $V$, que también atribuye erróneamente a Berruguete. Sarabia llama la atención sobre el interés demostrado por la Alhambra por diferentes viajeros extranjeros, señaladamente ingleses, con los que mantuvo una relación profesional que pretendía convertir también en una reclamación de la importancia que su propio trabajo tenía para la Academia. Para algunos de estos viajeros realizó dibujos del palacio nazarí, después de que hubieran visto "los borradores de la obra remitida" a la Academia y le hubieran solicitado copias de los dibujos de los diferentes edificios de la Alhambra, incluido el palacio de Carlos V. Pero ante esa petición Sarabia se excusaba "con el justo motivo de la grabedad de mi encargo, pues no estaba bien a mi estimación, que habiendo la real Academia cometidome esta delineazion, resultase en Reyno estraño salir al público grabados estos bestigios con el adictamento de ser diseñados por min. El celo que demostraba Sarabia también lo tuvo la Academia cuando la obra de las Antiguedades Arabes, ya grabados casi todos sus dibujos, esperaba su publicación, como se podrá comprobar posteriormente.

Entre los viajeros ingleses que cita hay que destacar la presencia del que Sarabia llama exclusivamente Pitt. Debe tratarse de Thomas Pitt, discipulo de Thomas Gray, uno de los más importantes protagonistas del gothic revival inglés, y sobrino de Charles Lyttelton, presidente de la Sociedad de Anticuarios de Londres y para el que hizo algunos dibujos en estilo gótico, participando también con otros diseños en el proyecto de 
Strawberry Hill de $H$. Walpole ${ }^{63}$. Pitt acompañó, en 1760, a Lord Strathmore en un viaje por España y Portugal, y sus dibujos y noticias de los edificios góticos y árabes de España fueron muy bien recibidas entre los anticuarios ingleses ya que venian a confirmar las tesis desarrolladas en el siglo anterior por Sir Christopher Wren ${ }^{64}$ sobre el origen "sarraceno" del gótico ${ }^{65}$, aunque es obvio que no todos compartian esa hipótesis.

En la copia del manuscrito del viaje de Pitt a España, realizada por W. Cole en 1772, afirma un tópico, que después se comentará en relación al estudio arquitectónico que habrá de realizar Hermosilla, sobre la imposibilidad de descubrir y trazar un plan unitario del palacio nazari, aunque, según confiesa Sarabia, dejó el encargo de realizarlo a "Oracio Maria Yusani Genobés residente en esta ciudad para que proporcionase su logro» ${ }^{66}$.

No eran esos, desde luego los intereses de Sarabia con respecto a la arquitectura árabe, a pesar de la importancia teórica e historiográfica que representa la presencia de los mencionados viajeros ingleses en la Alhambra, es más, T. Pitt ejerció una notable influencia sobre J. C. Murphy, cuya obra sobre los palacios nazaries habria de tener tanta importancia en Europa, aun cuando su deuda iconográfica con la obra de Hermosilla sea tan evidente. Aspecto, este último, que ha pasado incomprensiblemente desapercibido.

Para Sarabia, la presencia de estos viajeros ingleses no sólo tenia importancia con respecto a la empresa de dibujar y estudiar la arquitectura de los edificios de la Alhambra, sino que también servía para confirmar el enorme interés arqueológico de los descubrimientos realizados en las excavaciones de la Alcazaba. Él mismo se encargaba de acompañarles al lugar de los hallazgos y describe cómo "admiraron aquellos Monumentos tan extraños de Arquitectura" y también narra el hecho de que

63 Al respecto vease M. MC CARTHY. The origins of the Gothic Revival. obra citada, págs. 23 y 185. En general. sobre el gothic revival. veanse K. Clark. II Revival gotico. Turin, 1970; L. PATETTA, Lrarchitettura dell'Eclettismo. Milán, 1975 y P. Collins, Los ideales de la arquitectura moderna. Su evolucion (1750-1950). Barcelona, 1977.

64 B. LITTLE, Sir Christopher Wren, Londres, 1976; J. RYKWERT, Los primeros modernos... obra citada, págs. 124 y ss. y M. TAfuRi, "Architectura Artificialis": Claude Perrault, "Sir Christofer Wren y el debate sobre el lenguaje arquitectónico", en Retorica y Experimentalismo, Sevilla, 1978, págs. 243-286. Especial interés tienen, en este contexto. las páginas que dedica Wren al origen biblico de la arquitectura en Parentalia, Londres, 1750.

65 Sobre el origen "sarraceno» del gótico, veanse P. FRANKL. The Gothic. Princeton, 1960. págs. 370 y ss. y J. RYKWERT. Los primeros modernos.... obra citada, págs. 390-91. En relación a este problema véase el capitulo quinto

66 Sobre este personaje genoves no he podido encontrar dato alguno. 
algunos pretendieron adquirir algunos de los objetos encontrados, aunque Juan de Flores y sus compañeros se negaran a ello indicándoles que la excavación se realizaba por orden del Rey, "tan propensos son estas gentes a la estimación de estas cosas".

De nuevo, por via indirecta, el complejo asunto de las excavaciones de la Alcazaba encontraba una vinculación con su informe para la Academia. El texto, por otra parte, no podía terminar sin volver a meditar sobre la importancia de esos hallazgos y su relación con el propio "origen de la Arquitectura de los Arabes". La antigüedad y autenticidad de las inscripciones encontradas - "el caracter de estas inscripciones és anterior a todo lo mas antiguo que se enquentra en las Lapidas y medallas españolas" - vendría confirmada por el estudio arqueológico de la arquitectura, basado en una concepción biblica de la historia universal. Por otra parte, la declaración de principios realizada por Sarabia sobre la utilidad de la arquitectura en este tipo de estudios arqueológicos, tal como la formulara en su texto sobre la Alcazaba publicado por Medina Conde, mencionado anteriormente, encuentra su más perfecto ejemplo de aplicación precisamente en el informe que presentó a la Academia con el fin de explicar los dibujos enviados.

El alfabeto de esas antiquísimas inscripciones, dice Sarabia, era desconocido entre los eruditos. La consecuencia de esas observaciones se hacia inevitable. De nuevo Kircher parecia acudir en ayuda de las intenciones de Sarabia y de sus compañeros en las excavaciones de la Alcazaba. La arquitectura de esos restos, anteriores tanto a los romanos como a los árabes, revelaba su directa y estrecha vinculación con los fenicios. La lengua pura que Noé inauguró después del diluvio, escribe Sarabia, se extendió por el mundo. A pesar de la confusión de las lenguas después del episodio de la destrucción de la Torre de Babel, quedarían testimonios, en lugares muy apartados, de aquella lengua pura originaria, sufriendo un proceso de "connaturalización" - asi lo denomina nuestro autor- y dando lugar a la existencia de caracteres excepcionales que no serían sino la prueba de la venerable antigüedad de esos alfabetos y, también, de esa arquitectura. Es en la Alcazaba de Granada, en el lugar en el que los romanos fundaron la ciudad de lliberri, donde con anterioridad se habian refugiado, "en cuevas y grutas", los primeros pobladores de la ciudad que no eran sino "expedicionarios que envió Noé". Sobre estos primitivos refugios levantaron los romanos un templo que habria de ser la sede del "Concilio Ylliberitano", celebrado a comienzos del siglo Iv despues de Cristo, con lo que Granada pasaria a convertirse en la más antigua ciudad de la peninsula ibérica con testimonios del cristianismo primitivo. 
En este recinto sagrado, el edificio más importante conservado era el denominado templo de Apolo, del que conocemos el dibujo de su planta, obra de Sarabia, y publicado por Gómez Moreno ${ }^{67}$. Durante su estancia en Granada, Villanueva, por indicación de Hermosilla levantó planos del edificio, aunque no he podido localizarlos ${ }^{68}$. Si se conserva, sin embargo, otro plano del edificio realizado por Juan de Flores o alguno de sus ayudantes, probablemente anterior al de Sarabia ${ }^{69}$, que tiene el enorme interés de localizar en un impreciso dibujo, al menos desde el punto de vista de los sistemas de representación de la arquitectura, el lugar que ocupaban los diferentes restos (columnas, inscripciones, estatuas y otros objetos) encontrados en el lugar.

El «templo de Apolo», en realidad parece tratarse de la basílica de la ciudad ${ }^{70}$, tenía una peculiaridad que lo hacia también excepcional en el contexto de la arquitectura romana imperial. Esa "excelente fabrica», escribe Sarabia, tenia "capiteles de tan rara estructura que indemnizan ser anteriores a la Ynstituzion de las Cinco ôrdenes (y del mismo tiempo de las inscripciones raras que se demuestran)".

Esos extraños capiteles serian testimonio de una construcción anterior a la romana, obra de fenicios, de aquéllos "fenices arabes que binieron con Osiris a España». Sarabia precisa aún más: esos elementos «los reputo por de siglo coetaneo a los tiempos de Abraham". Estariamos, por tanto, ante unos capiteles anteriores a los del templo de Salomón. Es más, su rara forma parece prefigurar la reconstrucción que de los capiteles del templo hicieron Villalpando y Prado a finales del siglo XVI, no porque exista una meditación filológica semejante, sino porque un capitel más primitivo, como el que describe Sarabia, lejos de situarse en el orden cronológico vitruviano y de la teoría arquitectónica, del orden toscano al compuesto, del más sencillo al más elaborado, aparece como un antecedente antiguo del corintio, del mismo modo que el capitel del templo de Salomón reconstruido por Villalpando y Prado es también un

"M. Gomez Moreno, "Monumentos arquitectónicos...", obra citada, Lámina 48.

${ }^{68}$ En el estudio citado en la nota anterior. Gómez Moreno menciona que en la Academia de la Historia se conservaba un plano de Juan Flores. donación personal suya. asi como uno de Juan de Villanueva, de 1766, y tres de Sarabia, de 1768; estos últimos los habia pensado publicar A. Fernández Guerra. Ninguno de ellos puede localizarse ahora en la Academia de la Historia. Véase el capitulo tercero.

69 Pudiera tratarse de un plano identico al que Gomez Moreno donara a la Academia de la Historia. Se conserva en el ya citado legajo del Archivo de Simancas. Gracia y Justicia. Leg. 1027. aunque trasladado ahora a la sección de Mapas. planos y dibujos. sign.: XXXVi-51. junto con el resto de los dibujos del legajo mencionado.

70 Vease el capitulo tercero. 
capitel cercano al corintio y, desde su divina perfección, origen de los cinco órdenes canónicos de la tradición clasicista.

De ese extraño y raro capitel se conserva, afortunadamente, un dibujo en el Archivo General de Simancas, entre los muy numerosos que reproducen las antigüedades encontradas en la Alcazaba granadina ${ }^{71}$. Además del carácter rudimentario del diseño de las hojas de acanto y de los caulículos, presenta un insólito ábaco exagonal. Este curioso capitel fenicio, según Sarabia, seria, por tanto, anterior al sistema de los cinco órdenes clásicos y ajeno a sus principios, manteniendo una relación directa con los modelos de la arquitectura de la antigüedad bíblica. Es más, dado que, según nuestro autor, la lengua fenicia es casi la misma que la hebrea, la lengua que se habló en el Paraíso, estos capiteles derivarian de la arquitectura revelada por Dios y, como él mismo afirma, nada de esto está en Vitruvio. Si los caracteres desconocidos de las inscripciones encontradas en la Alcazaba podian ser definidos por los defensores de su autenticidad como el más antiguo "Alfabeto Nacional», la arquitectura practicada por sus autores tendría su emblema en esa suerte de "capitel nacional", de orden español ${ }^{72}$ que, además, no aparece con la voluntad de convertirse en un "sexto orden", sino situado en el origen mismo del sistema.

La evidencia documental, figurativa en el caso del capitel mencionado, convierte en simbólica la falsificación de un pasado diferente al clásico. Pero, quizás, lo más sugerente sea el empeño de Sarabia, y, con él, de los otros implicados en las excavaciones de la Alcazaba, de atribuir a esas memorias arqueológicas el valor añadido de las reliquias. Incluso, en este sentido, resulta absolutamente irrelevante que se trate de objetos auténticos o falsos, como se podrá comprobar posteriormente.

La "autenticidad" de esas falsificaciones y de sus coleccionistas, sin embargo, no fue entendida en los términos propuestos ni por sus contemporáneos ni por la historiografía posterior. Para Hermosilla, como antes para Luis José Velázquez, los descubrimientos de la Alcazaba, no parecian merecer el menor interés, aun cuando ambos reconocian la existen-

Véase nota 69.

En relación a este problema, véase $D$. Rodriguez Ruiz, "Del palacio del Rey al orden español...". obra citada. En general. sobre el "sexto orden" como ampliación del sistema canónico clásico, véase Perouse de Montclos, "Le sixieme ordre d'architecture ou la pratique des ordres suivant les nations". en Journal of the Societ of Architectural Historians, XXXVI, 1977, págs. 223-240; J. A. RamiREZ. “El sistema de los órdenes arquitectónicos o la utopía de la razón y el sueño de la libertad", en Edificios y sueños. Málaga, 1983. págs. 123-182. 
cia de algunos restos auténticos. El primero escribe, en diciembre de $1766^{73}$, a su hermano, Ignacio de Hermosilla, Secretario de la Academia de San Fernando, que ha visitado el lugar de las excavaciones, señalando que "todo aquello no vale dos pitos parece del medio tiempo pero no hay cosa concluida... hay tanta diversidad de vasas, colunas, trozos de capiteles todo tan discorde en figura, tamaño y materia que mas parece un taller de un escarpelino de Roma que edificio formal's. La observación de Hermosilla sería incluso utilizada en el juicio al que sometieron a los falsarios de la Alcazaba ${ }^{74}$, en el que, además, se pone de manifiesto que los implicados en las excavaciones, de Medina Conde y Juan de Flores al propio Sarabia, estaban convencidos de que los arquitectos enviados por la Academia pretendian realizar un informe sobre el asunto y no sólo rectificar los dibujos de la Alhambra realizados por el último.

Sin embargo, la tarea fundamental del viaje de Hermosilla a Granada será precisamente la rectificación y realización de los dibujos arquitectónicos de los palacios de la Alhambra. Sobre el resto de la obra de Sarabia, los dibujos de inscripciones y motivos decorativos del palacio nazari, Hermosilla no puso objeciones fundamentales y continuaron grabándose en Madrid mientras él permanecia en Granada. Otro tanto ocurría con las seis pinturas de Sarabia que reproducian las de la Sala de los Reyes, de las cuales sólo conozco la estampa grabada por Manuel Salvador Carmona en la que se deja impreciso y neutro el fondo de la escena de los dignatarios nazaries representados. Precisamente el fondo de estas pinturas sobre piel constituia un problema para los grabadores ya que Hermosilla afirmaba en sus cartas que Sarabia habia inventado algunos elementos, no ateniéndose al carácter documental y arqueológico que la Academia le habia exigido. Para evitar esas inexactitudes, Hermosilla realizó algunos dibujos a lápiz y pluma para que sirvieran de guía a los grabadores, indicando la escala y el plano de la superficie ocupada por las pinturas en las tres bóvedas asi como los colores que

Carta de José de Hermosilla a Ignacio de Hermosilla, fechada en Granada el doce de diciembre de 1766. A.S.F., sign 37-1/1

'sazón del Juicio.... obra citada, pág. 308. Hermosilla cuestionó además la propia existencia del templo ya que las "bases de las columnas", que podrian proporcionar alguna informacion sobre la forma del edificio, "no estan sobre fundamento sino sobre un pabimento que no se sabe que signifique". La afirmación se encuentra en la carta citada en la nota anterior. A pesar de todo, atendió la petición de la Academia de levantar algunos planos del lugar, que fueron realizados por Juan de Villanueva, como se ha mencionado anteriormente. Para Hermosilla todo el polémico descubrimiento se reducia a un "fanático" enirentamiento entre "Alcazabistas" o "Antialcazabistas", "y en no siendo de plomos y el concilio Yliberitano no ay que tratar de otra cosa". 
servian de fondo a las imágenes ${ }^{75}$, porque, como él mismo afirmaba, "en el Ayre es donde esta el yerro o añadidura de nubes y vagueza que no hay pues las unas estan sobre azul y las otras sobre oro a manera de los Mosaicos de Roma del Tiempo Barbaro".

Como ya indiqué al comienzo, los dibujos de arquitectura de la Alhambra realizados por Sarabia no se han conservado, probablemente debido a que sirvieron a Hermosilla para rectificar medidas y realizar anotaciones, con excepción de un capitel, posteriormente incluido por Hermosilla entre sus dibujos. Se trata de un magnífico testimonio de la espléndida policromía de los capiteles nazaries de la Alhambra que, por otra parte, sólo se conserva muy parcialmente, debido unas veces al deterioro ocasionado por el transcurrir del tiempo y, en otras, a intervenciones de limpieza realizadas, sobre todo, en el siglo $\mathrm{XIX}^{76}$.

i5 Los dibujos de Hermosilla acompañaban una carta suya a T. de Aguirre, fechada en Granada, el 28 de octubre de 1766. A.S.F., sign.: 37-1/1.

${ }^{75}$ A propósito de la policromia de los capiteles de la Alhambra, aparte de las conocidas ilustraciones de $\mathrm{O}$. Jones y J. Goury. Plans, elevations sections and details of the Alhambra. Londres, 1842-1845, véase P. MARINETTO, "La policromia de los capiteles del Palacio de los Leones", en Cuadernos de la Alhambra, v. 21. 1985, págs. 79-97. 
